\title{
Chemical Composition, Cytotoxic, Antimicrobial and Antioxidant Activities of Essential oil from Anthriscus caucalis M. Bieb Grown in China
}

\author{
Pengxiang Lai $\odot$, Huijuanzi Rao $\odot$ and Yang Gao $\odot *$ \\ Marine College, Shandong University, Weihai 264209, China \\ (Received July 19, 2017; Revised November 01, 2017; Accepted November 05, 2017)
}

\begin{abstract}
The essential oil of the aerial parts of Anthriscus caucalis M. Bieb was obtained by hydrodistillation and its components were analyzed by using GC and GC-MS. Forty-six compounds representing $97.2 \%$ of the total oil were identified. The main constituents in the oil were identified as $\beta$-Bisabolene $(28.4 \%)$, Germacrene D $(18.9 \%),(Z, E)-\alpha$-Farnesene $(16.8 \%)$ and $\gamma$-Muurolene (7.3\%). In vitro cytotoxicity evaluation against two cell lines of HepG2 (liver hepatocellular cells) and MCF-7 (human breast adenocarcinoma) cells showed a potent cytotoxic activity with the $\mathrm{IC}_{50}$ values of $67.50 \mu \mathrm{g} / \mathrm{mL}$ and $55.83 \mu \mathrm{g} / \mathrm{mL}$ according to the MTT assay. Furthermore, the essential oil exhibited a considerable activity against Bacillus subtilis and Escherichia coli with the MIC values of $0.095 \mathrm{mg} / \mathrm{mL}$ and $0.105 \mathrm{mg} / \mathrm{mL}$ tested by micro-dilution method. The antioxidant activity was evaluated by DPPH and FRAP methods, and the essential oil gave an $\mathrm{IC}_{50}$ value of $0.451 \mathrm{mg} / \mathrm{mL}$ and a Trolox equivalent antioxidant concentration of $191.7 \pm 11.3 \mu \mathrm{mol}$ Trolox $\times \mathrm{g}^{-1}$ in DPPH and FRAP, respectively. The results indicated that the essential oil was relatively active and may be useful in food and pharmaceuticals after more detailed study.
\end{abstract}

Keywords: Anthriscus caucalis M. Bieb; essential oil; antioxidant activity; antibacterial activity; cytotoxic activity. (C) 2018 ACG Publications. All rights reserved.

\section{Plant Source}

The aerial parts from Anthriscus caucalis M. Bieb were collected from southern hills of Xifeng County in Guizhou province of China, during September 2016. The plant material was identified by Associate Prof. Hong Zhao of the Marine College, Shandong University (Weihai). A voucher specimen (NO.10678) has been deposited at the Laboratory of Botany of Marine College, Shandong University.

\section{Previous Studies}

Anthriscus caucalis M. Bieb, an annual plant in the Apiaceae family, is a newly naturalized plant of Chinese Mainland and is native to and common in parts of Europe and Asia [1]. The

\footnotetext{
* Corresponding author: E- Mail: gygiang@163.com (Y. Gao), Phone +86-631-5688303.
} 
composition of the essential oil from Anthriscus caucalis M. Bieb (Ac-EO) collected in the urban area of Vienna has been studied, where the main compounds of all oils were cis-chrysanthenyl acetate (up to 74\%) and cis-chrysanthenol (up to $16 \%$ ) [2]. However, it is noteworthy that these two compounds were not found in present study.

\section{Present Study}

To the best of our knowledge, the composition of the essential oil of Anthriscus caucalis from China have not been investigated before, and there was no published study on the biological activities of essential oil of species. For this reason, we extracted essential oil of species by hydrodistillation and the chemical composition is identified by GC-FID and GC-MS (Gas Chromatography-Mass Spectrometer). Furthermore, we evaluated the antibacterial, cytotoxic and antioxidant activities of the studied oil. (See Supporting Information for the details of the experiment [3])

Table 1. Chemical composition of essential oil of A. caucalis M.Bieb

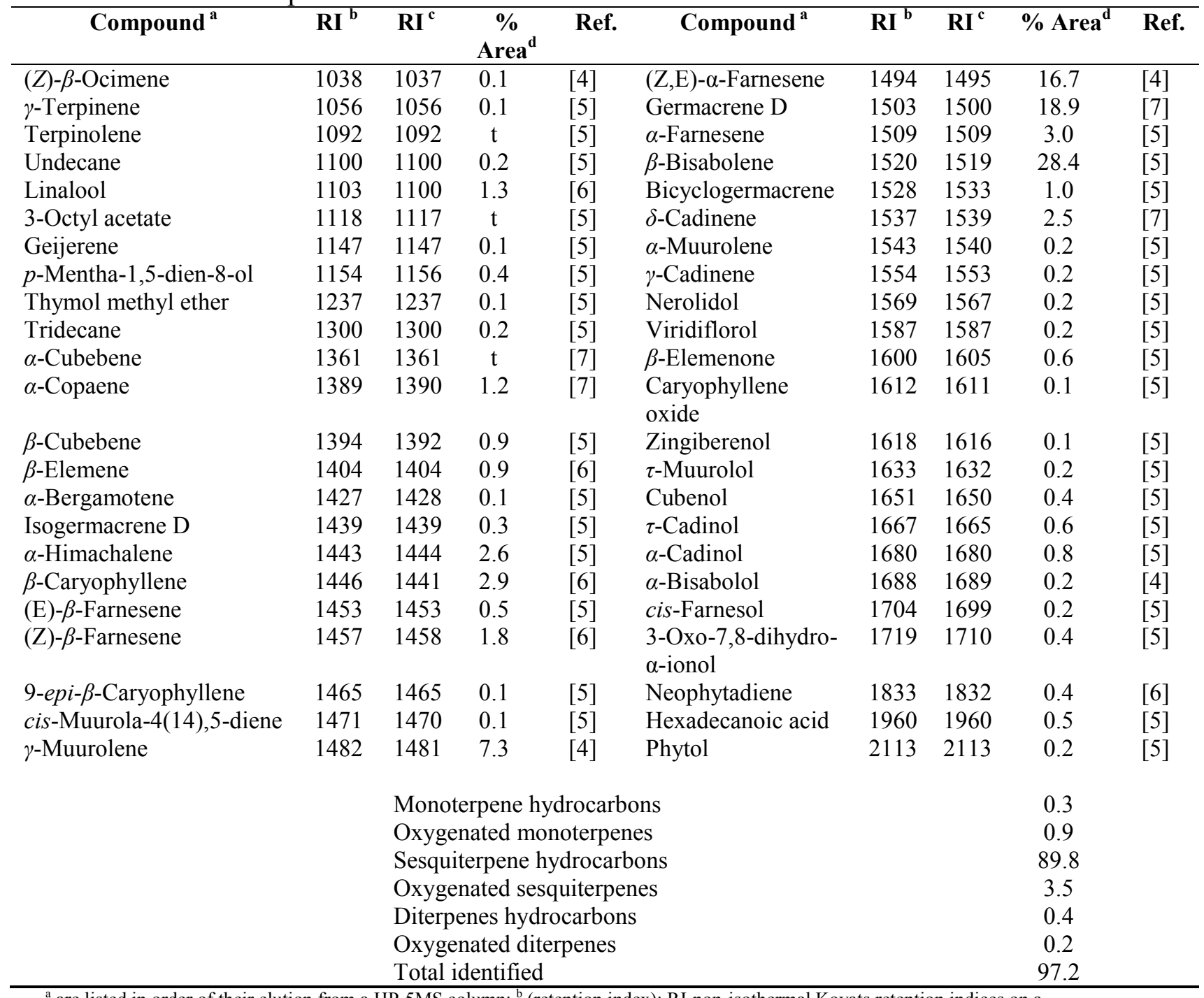

${ }^{\mathrm{a}}$ are listed in order of their elution from a HP-5MS column; ${ }^{\mathrm{b}}$ (retention index): RI-non-isothermal Kovats retention indices on a HP-5MS column relative to $\mathrm{C}_{10}-\mathrm{C}_{30} \mathrm{n}$-alkanes; ${ }^{\mathrm{c}}$ linear retention indices according to the literature and NIST Chemistry WebBook on a HP-5MS column; ${ }^{\mathrm{d}}$ The content (\%) of the individual components was calculated based on the peak area (FID response); t: trace $(<0.1 \%)$. 
The essential oil was yellow with a strong earthy odor. The GC-MS analyses revealed 46 compounds representing $97.2 \%$ of the oil. The identified compounds with their RI are listed in Table 1 (See Supporting Information). $\beta$-Bisabolene (28.4\%), germacrene D (18.9\%), (Z,E)- $\alpha$-Farnesene (16.8\%), $\gamma$-Muurolene (7.3\%), $\alpha$-Farnesene (3.0\%), $\beta$-Caryophyllene (2.9\%), $\alpha$-Himachalene $(2.6 \%)$ and $\delta$-Cadinene $(2.5 \%)$ were identified and found to be the predominant compounds in the essential oil. These compounds are encountered in other Anthriscus species in different proportions. For example, Germacrene D, was found to be one of the main compounds of A. cerefolium and A. nemorosa [3]. Moreover, the presence of sesquiterpenoids as the main components is in accordance with previous studies on species of the Anthriscus genus [8,9].

Cytotoxic activity test: The Cytotoxic activity of the essential oil was estimated using the MTT [3-(4,5-dimethylthiazol-2-yl)-2,5-diphenyltetrazolium bromide] assay against the HepG2 (liver hepatocellular cells) and MCF-7 (human breast adenocarcinoma cell line) cancer cell lines [10,11]. The result of cytotoxic activity test is given in Table 1.

According to the cytotoxic activity test, the growth of both cell lines was inhibited by essential oil of A. caucalis in a concentration-dependent manner. Likewise, cytotoxicity of the oil was increased as a function of duration of exposure, suggesting a time-dependent effect of the oil. The $\mathrm{IC}_{50}$ values for the cytotoxic effects of essential oil of A. caucalis on HepG2 and MCF-7 cells for $72 \mathrm{~h}$ were calculated to be $(67.50 \pm 17.70) \mu \mathrm{g} / \mathrm{mL}$ and $(55.83 \pm 8.34) \mu \mathrm{g} / \mathrm{mL}$, respectively.

The cytotoxic activity of essential oil of $A$. caucalis against the tested cells could be attributed to the presence of significant amounts of $\beta$-Bisabolene and $\beta$-Caryophyllene. $\beta$-Bisabolene, an intermediate in the biosynthesis of many other natural chemical compounds, exhibited potent antitumour properties against B16-F10, HepG2, HL-60 and MCF-7 cells lines [12,13]. Besides, $\beta-$ Caryophyllene also has been reported to potentiate the cytotoxic activity of paclitaxel against MCF-7, DLD-1 and L-929 tumor cell lines [14].

Antibacterial Activity test: The antibacterial activity of essential oil of A. caucalis was qualitatively and quantitatively assessed by the presence or absence of inhibition zone diameters and MIC values.

As presented in Table 3, essential oil of species showed a strong antibacterial activity against tested Gram-positive and Gram-negative bacteria strains. The best activities were observed against $B$. subtilis with an MIC value of $0.095 \mathrm{mg} / \mathrm{mL}$ followed by $E$. coli $(\mathrm{MIC}=0.105 \mathrm{mg} / \mathrm{mL}), S$. aureus (MIC $=0.150 \mathrm{mg} / \mathrm{mL})$, . aeruginosa $(\mathrm{MIC}=0.320 \mathrm{mg} / \mathrm{mL}$ ).

Table 2. Cytotoxic activity of essential oil of $A$. caucalis against HepG2 and MCF-7 cells

\begin{tabular}{|c|c|c|c|c|}
\hline & \multicolumn{4}{|c|}{$\mathrm{IC}_{50}(\mu \mathrm{g} / \mathrm{mL})$} \\
\hline & \multicolumn{2}{|c|}{ НерG-2 } & \multicolumn{2}{|c|}{ MCF-7 } \\
\hline & Ac-EO & Doxorubicin & Ac-EO & Doxorubicin \\
\hline $24 \mathrm{~h}$ & $114.53 \pm 14.74$ & $2.64 \pm 0.44$ & $95.88 \pm 6.12$ & $1.12 \pm 0.42$ \\
\hline $48 \mathrm{~h}$ & $91.03 \pm 6.54$ & $0.88 \pm 0.02$ & $79.65 \pm 6.58$ & $0.34 \pm 0.12$ \\
\hline $72 \mathrm{~h}$ & $67.50 \pm 17.70$ & $0.49 \pm 0.07$ & $55.83 \pm 8.34$ & $0.13 \pm 0.04$ \\
\hline
\end{tabular}

The strong antibacterial activity of essential oil against the tested bacteria could be attributed to the presence of high concentration of $\beta$-Bisabolene, Germacrene $\mathrm{D},(Z, E)$ - $\alpha$-Farnesene and $\beta$ Caryophyllene. $\beta$-Bisabolene has been reported to exhibit the potential to restore the effectiveness of ampicillin against resistant $S$. aureus [15]. Likewise, some studies demonstrated that Germacrene D, $(Z, E)-\alpha-$ Farnesene and $\beta$-Caryophyllene have significant antibacterial and antifungal activities [16-18]. 
Table 3. Antibacterial activity of essential oil of A. caucalis

\begin{tabular}{lcccc}
\hline \multicolumn{1}{c}{ Test strains } & \multicolumn{2}{c}{ Ac-EO } & \multicolumn{2}{c}{ chloramphenicol. } \\
\hline Gram positive & ZI $\left.^{\mathbf{a}} \mathbf{( m m}\right)$ & MIC $^{\mathbf{b}} \mathbf{( m g / \mathbf { m L } )}$ & ZI (mm) & MIC (mg/mL) \\
Staphylococcus aureus ATCC 6538 & $21.1 \pm 0.5$ & 0.150 & $27.8 \pm 0.9$ & 0.025 \\
Bacillus subtilis ATCC 6633 & $22.4 \pm 0.8$ & 0.095 & $30.2 \pm 1.0$ & 0.013 \\
Gram negative & & & & \\
Escherichia coli ATCC 25922 & $21.5 \pm 0.4$ & 0.105 & $32.5 \pm 0.5$ & 0.125 \\
Pseudomonas aeruginosa ATCC & $12.4 \pm 0.4$ & 0.320 & $15.5 \pm 0.4$ & 0.100 \\
27853 & &
\end{tabular}

$Z I^{\bar{a}}=$ The diameter of the inhibition zones $(\mathrm{mm})$, including the disc diameter $(6 \mathrm{~mm})$, are given as the mean $\pm S D$ of triplicate experiments and $M I C^{b}=$ minimum inhibitory concentration

Antioxidant activity test: A single assay does not accurately account for all of the groups of antioxidant compounds, particularly in a complex system. Therefore, essential oil of A. caucalis was subjected to screening for the possible antioxidant activity by two methods namely DPPH $(2,2-$ diphenyl-1-picrylhydrazyl) radical-scavenging [19] and ferric reducing antioxidant power (FRAP) assays [20]. The results are presented in Table 4.

It was observed that essential oil of $A$. caucalis exhibited a weak DPPH radical-scavenging activity with an $\mathrm{IC}_{50}$ value of $0.451 \mathrm{mg} / \mathrm{mL}$ compared with the standard, $\mathrm{BHT}\left(\mathrm{IC}_{50}\right.$ value of 0.043 $\mathrm{mg} / \mathrm{mL}$ ). In view of the results of FRAP assay, the essential oil showed a moderate ferric ion reducing activity (Trolox equivalent antioxidant concentration $=191.7 \pm 11.3 \mu \mathrm{mol}$ Trolox $\times \mathrm{g}^{-1}$ ).

Table 4. Results of antioxidant activity in vitro (DPPH, FRAP) of essential oil of A. caucalis

\begin{tabular}{ccc} 
Test Sample & DPPH IC $_{50}(\mathrm{mg} / \mathrm{ml})^{\mathrm{a}}$ & FRAP $\left(\mu \mathrm{mol}\right.$ Trolox $\left.\times \mathrm{g}^{-1}\right)$ \\
\hline Ac-EO & $0.451 \pm 0.032$ & $191.7 \pm 11.3$ \\
BHT $^{\mathrm{b}}$ & $0.043 \pm 0.001$ & \\
\hline Note:Each value is presented as mean \pm standard deviation $(\mathrm{n}=3)$. \\
${ }^{\mathrm{a}} \mathrm{IC}_{50}=$ The concentration of compound that affords a $50 \%$ reduction in the assay. \\
${ }^{\mathrm{b}}$ Positive control used.
\end{tabular}

\section{Acknowledgments}

This research was financially supported by the Shandong Science and Technology Program (ZR2014HM018).

\section{Supporting Information}

Supporting Information accompanies this paper on http://www.acgpubs.org/RNP

\section{ORCID}

Pengxiang Lai: 0000-0002-5380-4382

Yang Gao: 0000-0001-9695-5511

Huijuanzi Rao: 0000-0002-2704-296X

\section{References}

[1] Z. Dong, Q. Liu, J. Hu, M. Deng and Y. Xiong (2013). New records of naturalized plants from the Chinese Mainland, Guang. Zhiwu/Guihaia. 33, 432-434.

[2] R. Chizzola (2011). Composition of the essential oils from Anthriscus cerefolium var. trichocarpa and A. caucalis growing wild in the urban area of Vienna (Austria), Nat. Prod. Commun. 6, 1147-1150. 
[3] P. Evangelia, V. Constantinos, C. Maria and T. Olga (2017). Study of volatile components of Acacia farnesiana Willd. Flowers, Rec. Nat. Prod. 11, 474-478.

[4] G. M. Petrović, J. G. Stamenković, I. R. Kostevski, G. S. Stojanović, V. D. Mitić and B. K. Zlatković (2017). Chemical composition of volatiles; antimicrobial, antioxidant and cholinesterase inhibitory activity of Chaerophyllum aromaticum L.(Apiaceae) essential oils and extracts, Chem Biodivers. 14, 1612-1872.

[5] P. J. Linstrom and W. G. Mallard (2014). NIST Chemistry WebBook, NIST Standard Reference Database Number 69. (http://webbook.nist.gov).

[6] H. Rao, P. Lai and Y. Gao (2017). Chemical composition, antibacterial activity, and synergistic effects with conventional antibiotics and nitric oxide production inhibitory activity of essential oil from Geophila repens (L.) IM Johnst, Molecules. 22, 1561-1574.

[7] M. F. Karlsson, G. R. Birgersson, A. M. Cotes Prado, F. Bosa, M. Bengtsson and P. Witzgall (2009). Plant odor analysis of potato: Response of Guatemalan moth to above- and belowground potato volatiles, J. Agr. Food Chem. 57, 5903-5909.

[8] Ö. Kiliç (2017). Essential oil composition of aerial parts of two Anthriscus Pers. species from Turkey, JEOBP. 20, 591-596.

[9] S. Hayta, G. Dogan, A. Demirpolat and E. Bagci (2015). Identification of essential oil composition of four umbelliferae from Turkey, Nat. Sci.Discover. 1, 74-92.

[10] O. Firuzi, K. Javidnia, M. Gholami, M. Soltani and R. Miri (2010). Antioxidant activity and total phenolic content of 24 Lamiaceae species growing in Iran, Nat. Prod. Commun. 5, 261-264.

[11] T. Mosmann (1983). Rapid colorimetric assay for cellular growth and survival: Application to proliferation and cytotoxicity assays, J. Immunolog. Method. 65, 55-63.

[12] S. K. Yeo, A. Y. Ali, O. A. Hayward, D. Turnham, T. Jackson, I. D. Bowen and R. Clarkson (2016). $\beta$ bisabolene, a sesquiterpene from the essential oil extract of Opoponax (Commiphora guidottii), exhibits cytotoxicity in breast cancer cell lines, Phytother. Res. 30, 418-425.

[13] A. C. B. Rodrigues, L. M. Bomfim, S. P. Neves, L. R. Menezes, R. B. Dias, M. B. Soares, A. P. N. Prata, C. A. G. Rocha, E. V. Costa and D. P. Bezerra (2015). Antitumor properties of the essential oil from the leaves of Duguetia gardneriana, Planta Med. 81, 798-803.

[14] J. Legault and A. Pichette (2007). Potentiating effect of $\beta$-caryophyllene on anticancer activity of $\alpha$ humulene, isocaryophyllene and paclitaxel, J. Pharm. Pharmacol. 59, 1643-1647.

[15] A. M. Nascimento, M. G. Brandao, G. B. Oliveira, I. C. Fortes and E. Chartone-Souza (2007). Synergistic bactericidal activity of Eremanthus erythropappus oil or $\beta$-bisabolene with ampicillin against Staphylococcus aureus, Antonie van Leeuwen. 92, 95-100.

[16] F. Şahin, M. Güllüce, D. Daferera, A. Sökmen, M. Sökmen, M. Polissiou, G. Agar and H. Özer (2004). Biological activities of the essential oils and methanol extract of Origanum vulgare ssp. vulgare in the Eastern Anatolia region of Turkey, Food Control 15, 549-557.

[17] A. Chehregani, F. Mohsenzadeh, N. Mirazi, S. Hajisadeghian and Z. Baghali (2010). Chemical composition and antibacterial activity of essential oils of Tripleurospermum disciforme in three developmental stages, Pharmaceut. Biol. 48, 1280-1284.

[18] A. Y. Al-Maskri, M. A. Hanif, M. Y. Al-Maskari, A. S. Abraham, J. N. Al-sabahi and O. Al-Mantheri (2011). Essential oil from Ocimum basilicum (Omani Basil): a desert crop, Nat. Prod. Commun. 6, 1487-1490.

[19] T. Yamaguchi, H. Takamura, T. Matoba and J. Terao (1998). HPLC method for evaluation of the free radical-scavenging activity of foods by using 1,1-diphenyl-2-picrylhydrazyl, Biosci. Biotechnol. Biochem. 62, 1201-1204.

[20] L. Müller, K. Fröhlich and V. Böhm (2011). Comparative antioxidant activities of carotenoids measured by ferric reducing antioxidant power (FRAP), ABTS bleaching assay ( $\alpha$ TEAC), DPPH assay and peroxyl radical scavenging assay, Food Chem. 129, 139-148.

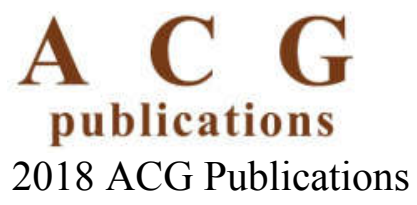

